\title{
A TOXICIDADE EM AMBIENTES AQUÁTICOS: DISCUSSÃO E MÉTODOS DE AVALIAÇÃO
}

\author{
Carla Regina Costa e Paulo Olivi* \\ Departamento de Química, Faculdade de Filosofia, Ciências e Letras de Ribeirão Preto, Universidade de São Paulo, Av. Bandeirantes, \\ 3900, 14040-901 Ribeirão Preto - SP, Brasil \\ Clarice M. R. Botta e Evaldo L. G. Espindola \\ Núcleo de Estudos em Ecossistemas Aquáticos, Centro de Recursos Hídricos e Ecologia Aplicada, Escola de Engenharia de São \\ Carlos, Universidade de São Paulo, CP 292, 13560-970 São Carlos - SP, Brasil
}

Recebido em 5/10/07; aceito em 31/1/08; publicado na web em 24/9/08

\begin{abstract}
TOXICITY IN AQUATIC ENVIRONMENTS: DISCUSSION AND EVALUATION METHODS. Aquatic toxicity tests are assays performed with different aquatic organisms of different ecological organization levels. Such tests are a source of information on the toxicity of a given substance or wastewater under controlled conditions, and they complement the physico-chemical analyses. Moreover, they allow one to evaluate the risks resulting from the presence of toxic substances in the environment. Algae, crustaceans, fishes and bacteria are frequently used in toxicity tests. In this work, we will present the main aspects related to the aquatic toxicity tests and a discussion of their applicability will also be presented.
\end{abstract}

Keywords: aquatic ecotoxicology; toxicity tests; dose-response relationship.

\section{INTRODUÇÃO}

Testes de toxicidade são ensaios laboratoriais, realizados sob condições experimentais específicas e controladas, utilizados para estimar a toxicidade de substâncias, efluentes industriais e amostras ambientais (águas ou sedimentos). Nesses ensaios, organismos-testes são expostos a diferentes concentrações de amostra e os efeitos tóxicos produzidos sobre eles são observados e quantificados..$^{1-3}$ Os testes de toxicidade não permitem obter uma resposta absoluta sobre o risco que uma determinada amostra apresenta para a população humana, uma vez que é muito difícil extrapolar para os seres humanos os resultados de toxicidade obtidos para os organismos em laboratório e até mesmo correlacionar os resultados de toxicidade entre organismos de diferentes espécies. ${ }^{1}$

Testes de toxicidade são ferramentas desejáveis para avaliar a qualidade das águas e a carga poluidora de efluentes, uma vez que somente as análises físico-químicas tradicionalmente realizadas, tais como demanda química de oxigênio (DQO), demanda bioquímica de oxigênio (DBO), sólidos suspensos, concentrações de metais e de outras substâncias de caráter orgânico ou inorgânico, cujos limites encontram-se estabelecidos nas legislações ambientais, não são capazes de distinguir entre as substâncias que afetam os sistemas biológicos e as que são inertes no ambiente e, por isso, não são suficientes para avaliar o potencial de risco ambiental dos contaminantes. Apesar disso, os testes de toxicidade não substituem as análises químicas tradicionais. Enquanto as análises químicas identificam e quantificam as concentrações das substâncias tóxicas, os testes de toxicidade avaliam o efeito dessas substâncias sobre sistemas biológicos. Assim, as análises químicas e os testes de toxicidade se complementam. Em se tratando de amostras de natureza química complexa, como é o caso de efluentes industriais, os quais são constituídos por uma variedade de substâncias químicas, seria analítica e economicamente inviável detectar, identificar e quantificar todas as substâncias presentes, mesmo que os padrões de emissão fossem estabelecidos para cada uma delas. Além disso, somente

\footnotetext{
*e-mail: olivip@ @fclrp.usp.br
}

com a identificação e a quantificação dessas substâncias não seria possível estimar os efeitos que elas apresentam sobre a biota, uma vez que a atividade biológica de uma substância pode depender de suas interações com os outros componentes do efluente, incluindo aqueles que não são tóxicos mas que afetam as propriedades químicas ou físicas do sistema e, conseqüentemente, as condições de vida dos organismos. Assim, é impossível identificar uma única substância como responsável por um determinado efeito tóxico. ${ }^{2,4-6}$

A ciência que estuda os efeitos nocivos causados por substâncias químicas sobre organismos vivos é chamada toxicologia. ${ }^{7-9}$ Por convenção, essa ciência também estuda os efeitos danosos causados por agentes físicos, tais como radiações de diferentes tipos e poluição sonora. ${ }^{9}$ A toxicologia tem como principais objetivos identificar os riscos associados a uma determinada substância e determinar em quais condições de exposição esses riscos são induzidos. ${ }^{10}$ A ocorrência, natureza, incidência, mecanismo e fatores de risco associados às substâncias tóxicas são parâmetros experimentalmente investigados pela toxicologia. ${ }^{10}$ Ela não serve somente para proteger os seres vivos e o ambiente dos efeitos deletérios causados pelas substâncias tóxicas, mas também para facilitar o desenvolvimento de agentes químicos nocivos mais seletivos, tais como drogas clínicas e pesticidas. ${ }^{9}$

A toxicologia compreende basicamente os seguintes ramos: ${ }^{7,9}$ toxicologia clínica, a qual estuda o efeito de drogas sobre pacientes humanos; toxicologia forense, cujo objetivo é detectar o uso ilegal de agentes tóxicos para fins judiciais e toxicologia ambiental, a qual se preocupa com o destino dos agentes tóxicos, seus metabólitos e produtos de degradação no ambiente e nas cadeias alimentares e com o efeito desses contaminantes sobre os organismos e as populações. Esse último ramo considera que a sobrevivência humana depende do bem-estar de outras espécies e da disponibilidade de ar, água, solo e alimentos limpos e considera também que as substâncias químicas antropogênicas podem causar efeitos danosos aos organismos vivos e aos processos biológicos. Embora na definição de toxicologia ambiental estejam incluídas substâncias químicas tóxicas naturalmente encontradas no ambiente, como venenos animais e toxinas microbianas e vegetais, a toxicologia ambiental é tipicamente associada com o estudo de agentes químicos de origem antropogênica. ${ }^{9,11}$ 
Assim, a toxicologia ambiental se preocupa com a influência que os agentes tóxicos ambientais exercem sobre a saúde e o bem-estar de humanos, animais e plantas, por meio da interação desses organismos. ${ }^{11}$ A toxicologia ambiental é uma ciência altamente eclética e multidisciplinar que envolve diversas áreas de estudo como biologia, química (orgânica, analítica e bioquímica), anatomia, genética, fisiologia, microbiologia, ecologia, ciências do solo, água e atmosfera, epidemiologia, estatística e legislação. ${ }^{7,9,11}$ Os objetos de estudo de algumas dessas áreas são apresentados na Figura 1 . $^{7}$

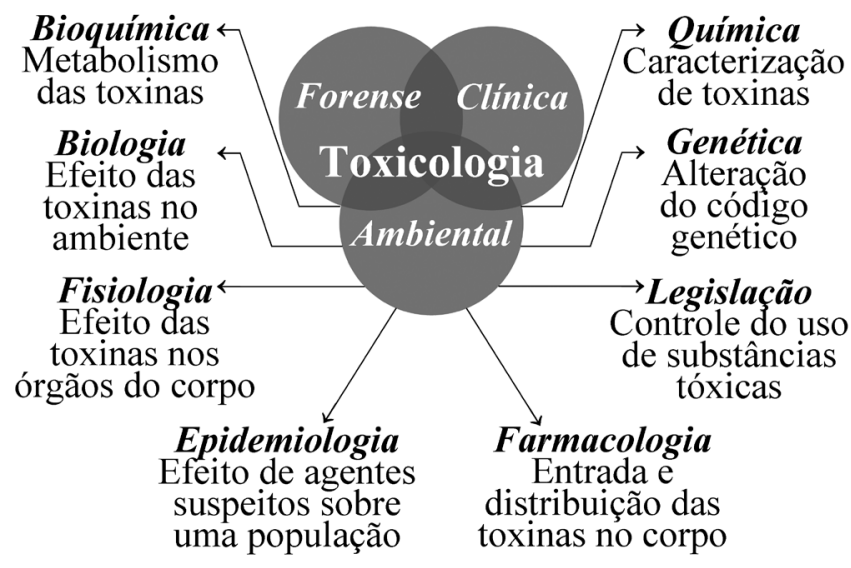

Figura 1. Objetos de estudo de algumas áreas compreendidas pela toxicologia ambiental

A ecotoxicologia é uma área especializada da toxicologia ambiental que centra seus estudos nos efeitos ocasionados por agentes químicos e físicos sobre a dinâmica de populações e comunidades integrantes de ecossistemas definidos. ${ }^{2,8} \mathrm{O}$ termo ecotoxicologia é algumas vezes utilizado como sinônimo do termo toxicologia ambiental, entretanto, este último também abrange os efeitos dos agentes químicos do ambiente sobre os seres humanos. ${ }^{12}$ Basicamente, a ecotoxicologia compreende a seqüência de eventos apresentada na Figura 2, a qual é referida como cadeia da causalidade. ${ }^{13}$ As informações obtidas por meio dessa cadeia são essenciais para: determinar os níveis de contaminantes no ambiente e seus destinos; estimar o grau de periculosidade dos contaminantes e seus metabólitos para os organismos vivos; indicar níveis máximos permitidos de contaminantes, ou seja, os padrões a serem mantidos; diagnosticar e prognosticar o efeito dos contaminantes no ambiente e o efeito das medidas tomadas; controlar a emissão de efluentes e avaliar os riscos ecológicos. ${ }^{13}$

A ecotoxicologia aquática tem como objetivo avaliar o efeito de substâncias químicas tóxicas sobre organismos representativos do ecossistema aquático. ${ }^{14}$ Os efeitos tóxicos podem se manifestar em diferentes níveis de organização, desde estruturas celulares até indivíduos, populações e comunidades. ${ }^{2,15}$ A ecotoxicologia aquática envolve o transporte, a distribuição, a transformação e o destino final dos contaminantes no ambiente aquático. ${ }^{16}$ Os testes de toxicidade aquática são bastante utilizados porque os ecossistemas aquáticos constituem os principais receptáculos de contaminantes, sejam eles lançados diretamente nos corpos d'água por meio das descargas de efluentes, emitidos no ar ou depositados nos solos. ${ }^{4,8}$

\section{O AMBIENTE AQUÁTICO}

O ambiente aquático é altamente complexo e diverso. Ele compreende vários tipos de ecossistemas dentre os quais se encontram rios, lagos, estuários, mares e oceanos. Todos esses ecossistemas são produtos dinâmicos de interações complexas entre os componentes bióticos e abióticos característicos de cada um deles. ${ }^{14}$

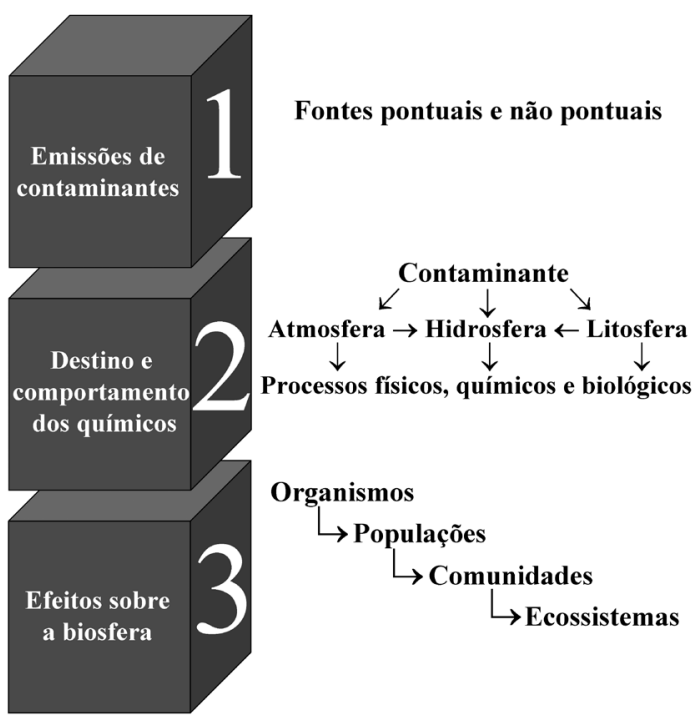

Figura 2. Seqüência de etapas compreendidas pela ecotoxicologia e denominada cadeia da causalidade

As propriedades físicas e químicas dos ecossistemas aquáticos podem afetar significativamente a atividade biológica e o impacto dos agentes químicos e outros xenobióticos. A vulnerabilidade do ambiente aquático às substâncias químicas depende: das propriedades físicas e químicas dos contaminantes e dos produtos resultantes de sua transformação; da concentração dos contaminantes no ecossistema; da duração e do tipo de descarga dos contaminantes (descarga intermitente ou contínua); das propriedades do ecossistema que lhe permitem resistir às alterações resultantes da presença dos contaminantes, como a capacidade tamponante das águas e a concentração de matéria orgânica dissolvida nelas e, da localização do ecossistema em relação ao sítio de lançamento dos contaminantes. ${ }^{14}$

Os sistemas aquáticos naturais são abertos e dinâmicos e por isso sofrem modificações contínuas na sua composição química. As águas marinhas são constituídas principalmente por íons cloreto, sódio, cálcio, potássio, magnésio e sulfato, os quais são denominados componentes conservativos. Eles constituem aproximadamente $99 \%$ da massa total de sólidos dissolvidos na água do mar, sendo que os íons cloreto e sódio respondem sozinhos por aproximadamente $86 \%$. Nas águas doces, cálcio, magnésio e carbonato são os íons mais abundantes. Compostos de sódio, potássio, fósforo, ferro, enxofre e silício também estão presentes nessas águas. Além de componentes conservativos, as águas também são constituídas por componentes não conservativos, os quais incluem: gases dissolvidos como $\mathrm{O}_{2}, \mathrm{CO}_{2}$ e $\mathrm{N}_{2}$; nutrientes como fosfato e nitrato; compostos orgânicos dissolvidos como aminoácidos e substâncias húmicas; elementos traços como cobre, zinco, cromo, molibdênio, vanádio, manganês, estanho, ferro, níquel, cobalto e selênio e, materiais particulados como areia, argila, colóides, tecidos não vivos e excretos. ${ }^{14,17}$

Oxigênio e dióxido de carbono são os dois gases mais abundantes nas águas doces e marinhas. O oxigênio é importante porque atua como regulador em processos metabólicos dos organismos e comunidades. Grande parte do oxigênio dissolvido nas águas doce e salgada provém da atmosfera, mas ele também é produzido pela ação fotossintética das algas. Dióxido de carbono atua como tampão impedindo que mudanças bruscas de $\mathrm{pH}$ ocorram nas águas naturais. Em solução ele participa das reações de equilíbrio envolvendo os íons carbonato e bicarbonato. Bicarbonato é a espécie predominante nas águas naturais com $\mathrm{pH}$ entre 6 e 10 . Abaixo de $\mathrm{pH} 6$ a espécie predominante é o dióxido de carbono e acima de $\mathrm{pH} 10$, o íon carbonato é predominante. Dióxido de carbono também participa como regulador em certos processos biológicos que ocorrem no ambiente aquático 
como no crescimento de plantas e na respiração animal. ${ }^{14}$

A concentração, transporte, transformação e disposição final de um contaminante introduzido no ambiente aquático dependem, principalmente, das propriedades do ambiente e das características do contaminante. ${ }^{14}$ As emissões de contaminantes no ar, no solo e principalmente nas águas (etapa 1, Figura 2) estão relacionadas aos processos naturais e, principalmente, às atividades humanas. As fontes de poluição podem ser classificadas em pontuais e não pontuais. ${ }^{18}$ Dentre as fontes pontuais podemos citar as estações de tratamento de efluentes industriais, redes de esgoto doméstico, derramamentos acidentais e mineração. As emissões de fontes pontuais são mais facilmente detectadas e controladas e, geralmente, resultam em descargas diretas dos contaminantes nos corpos d'água. Ao contrário, as emissões de fontes não pontuais são de difícil controle, variam com o tempo e espaço e podem envolver rotas que resultem na deposição parcial dos contaminantes antes deles atingirem os corpos d'água. Um exemplo típico de fonte não pontual é a utilização de pesticidas no solo.

Uma vez no ambiente, os contaminantes podem estar sujeitos a uma combinação de processos que podem afetar o seu destino e comportamento. ${ }^{18,19}$ As substâncias potencialmente tóxicas podem ser degradadas por processos abióticos e bióticos que ocorrem na natureza. No entanto, algumas delas resistem aos processos de degradação e por isso são capazes de persistirem no ambiente por longos períodos de tempo. O descarte contínuo no ambiente de uma substância persistente pode levar à sua acumulação em níveis ambientais suficientes para resultar em toxicidade. ${ }^{20}$

No ambiente aquático, os contaminantes podem ser envolvidos em processos de transporte e transferência de fase, em processos de transformação e em processos de assimilação ${ }^{18}$ (etapa 2, Figura 2). Os processos incluídos na primeira categoria não são degradativos, enquanto que os das duas últimas categorias são. ${ }^{9}$ Na Figura 3 são apresentados alguns processos de transporte e transformação dos contaminantes no ambiente aquático.

Os processos de transporte e transferência de fase determinam a distribuição temporal de um contaminante no ambiente. ${ }^{18}$ No ambiente aquático, encontram-se entre esses processos: volatilização e deposição úmida, processos de sorção (adsorção e dessorção), dissolução e precipitação e, sedimentação e ressuspensão. ${ }^{18,21-23}$

Contaminantes orgânicos que apresentam alta pressão de vapor e baixa solubilidade em água, como benzeno, clorofórmio, diclorometano e tetracloreto de carbono, tendem a volatilizar. ${ }^{13,24} \mathrm{~A}$ volatilização ocorre por um mecanismo difusivo no qual o contaminante

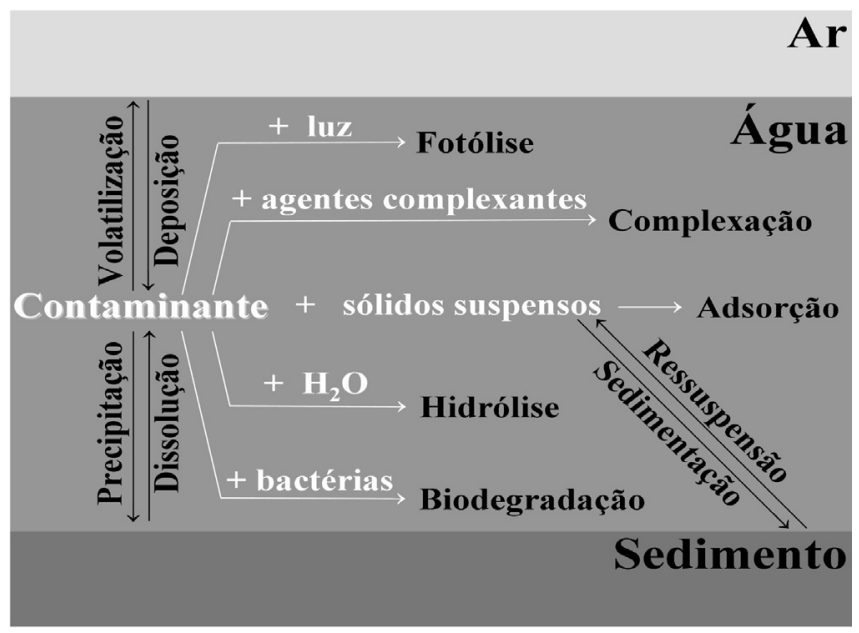

Figura 3. Alguns processos de transporte e transformação que ocorrem no ambiente é transferido de um compartimento ou fase onde a fugacidade é alta para outra onde a fugacidade é menor, até que seja atingido um equilíbrio termodinâmico entre ambas as fases. Processos difusivos são bidirecionais e a direção do transporte do contaminante depende da sua concentração nas fases envolvidas. ${ }^{21}$

Contaminantes com baixa pressão de vapor e baixa solubilidade em água tendem a se adsorver nos materiais particulados e nos sedimentos. ${ }^{13}$ Os sedimentos são as camadas de partículas minerais e orgânicas finamente granuladas que estão em contato com a parte inferior dos corpos d'água naturais. Metais pesados, pesticidas e hidrocarbonetos aromáticos polinucleados podem se adsorver nos sedimentos e, em seguida, podem ser transferidos para os organismos que os habitam. ${ }^{25}$

A dissolução é a principal rota pela qual várias substâncias entram nos corpos d'água. Contaminantes com alta solubilidade em água tendem a permanecer nela. Em se tratando de contaminantes orgânicos, grupos polares como hidroxilas, aminas e carboxilas aumentam sua solubilidade em água e fazem com que eles sejam volatilizados mais lentamente. ${ }^{13}$

Os principais processos de transformação que ocorrem no ambiente aquático são a hidrólise, a fotólise, a complexação e a biodegradação (Figura 3). ${ }^{18,22,23,26}$ Esses processos são importantes porque determinam a persistência dos contaminantes no ambiente. ${ }^{18}$

A hidrólise é uma reação importante porque os produtos resultantes dela são tipicamente mais solúveis em água e por isso são menos biodisponíveis e menos voláteis do que seus precursores. A velocidade das reações de hidrólise depende de um grande número de variáveis ambientais como $\mathrm{pH}$, temperatura, presença de catalisadores, sorção sobre sólidos e força iônica. São exemplos desse tipo de reação a conversão de haletos de alquila a álcoois, de ésteres a ácidos e de epóxidos a dióis..$^{22,23,26}$ Paration $^{\circledR}$, um pesticida organofosforado, é altamente susceptível à hidrólise, o que diminui o seu tempo de vida no ambiente aquático. Os produtos resultantes da hidrólise do Paration ${ }^{\circledR}$ são o dietilfosforotioato e o $p$-nitrofenol. ${ }^{20}$

A luz, principalmente a radiação UV, é capaz de provocar a quebra de ligações químicas e assim contribuir significativamente para degradar algumas substâncias. As reações fotoquímicas podem ser responsáveis por uma variedade de transformações, incluindo oxidação, hidroxilação, ciclização e desalogenação. Para que elas ocorram é necessário que a luz solar penetre no ambiente aquático. No entanto, parte da radiação solar é absorvida pela matéria dissolvida e particulada, o que atenua a intensidade da luz nas camadas de água mais profundas. Assim, as reações fotoquímicas ocorrem mais freqüentemente na atmosfera e nas águas superficiais e podem provocar a degradação de compostos tóxicos ou, ainda, promover um aumento na toxicidade de compostos inicialmente pouco tóxicos. ${ }^{9,26}$ Diclofenaco, por exemplo, foi encontrado em águas superficiais na Alemanha em concentrações acima de $2 \mu \mathrm{g} \mathrm{L}{ }^{-1} \cdot{ }^{27}$ Quando exposto à luz solar ele se decompõe rapidamente, originando compostos como 2-cloroanilina, 2,6-dicloroanilina, 2,6-diclorofenol e outros. Cianocomplexos, como hexacianocobaltato(III), também são fotodissociados em água liberando íons cianeto, os quais são extremamente tóxicos. Na ausência de luz, o hexacianocobaltato(III) mostrou-se moderadamente tóxico aos microcrustáceos Daphnia magna e Ceriodaphnia dubia e praticamente atóxico ao peixe Oncorhynchus mykiss mas, na presença de radiação emitida por um simulador solar, tornou-se altamente tóxico para ambas as espécies de crustáceos e, principalmente, para a espécie de peixe. ${ }^{28}$

A toxicidade dos metais depende da forma química que assumem no ambiente aquático. Há evidências de que processos capazes de reduzir a concentração dos íons metálicos livres como, por exemplo, reações de complexação, podem diminuir significativamente sua toxicidade. No ambiente aquático, metais podem se complexar com a 
matéria orgânica dissolvida, principalmente com substâncias húmicas. Essas representam $80 \%$ da matéria orgânica dissolvida nas águas naturais e influenciam numerosos processos biogeoquímicos..$^{29,30}$

Apesar de muitos contaminantes serem susceptíveis aos processos de degradação abióticos, tais processos geralmente são muito lentos. Degradações mais rápidas dos contaminantes podem ocorrer por meio da ação de microorganismos. ${ }^{20}$ Os microorganismos, tais como bactérias e fungos, são capazes de degradar as substâncias orgânicas porque elas servem como fonte de carbono para seu crescimento e manutenção. ${ }^{22}$ Os fatores que influenciam a biodegradação desses contaminantes são: a disponibilidade de microorganismos apropriados, a susceptibilidade dos contaminantes à degradação biológica e as condições ambientais, tais como temperatura, $\mathrm{pH}$, disponibilidade de nutrientes, nível de oxigênio, etc. Além desses, a disponibilidade das substâncias aos microorganismos pode desempenhar um papel importante. De forma geral, somente espécies dissolvidas são absorvidas pelos organismos e degradadas no interior das células. Transformações extracelulares por enzimas excretadas também são possíveis e podem afetar inclusive compostos adsorvidos nos materiais particulados e sedimentos. ${ }^{26}$

A biodegradação pode ocorrer sob condições aeróbias e anaeróbias. Na biodegradação aeróbia, os organismos utilizam o oxigênio como receptor de elétrons no metabolismo, enquanto que na biodegradação anaeróbia são utilizados substratos eletrofílicos, como sulfato e nitrato. Os processos aeróbios são mais rápidos do que os anaeróbios nas águas superficiais devido ao maior número de microorganismos aeróbios com crescimento rápido. ${ }^{22}$

As seguintes características moleculares geralmente aumentam a biodegradabilidade aeróbia das substâncias: grupos susceptíveis à hidrólise enzimática, tais como ésteres; átomos de oxigênio na forma de grupos hidroxilas, aldeídos, ácidos carboxílicos e cetonas; cadeias alquílicas lineares não substituídas e anéis fenílicos. Por outro lado, a presença de halogênios na molécula; extensas ramificações na cadeia; grupos nitro, azo, arilamino e aminas terciárias; resíduos policíclicos, tais como hidrocarbonetos aromáticos policíclicos e, resíduos heterocíclicos como imidazol são algumas características que aumentam a resistência das substâncias à biodegradação aeróbia. ${ }^{31}$

$\mathrm{Na}$ área de ecotoxicologia, décadas de pesquisa e testes com várias substâncias orgânicas têm levado a uma série de generalizações sobre como a toxicidade aquática pode ser reduzida, por meio de modificações das estruturas e das propriedades das substâncias. Assim, o aumento do peso molecular de uma substância para valores maiores do que 1000 , a redução da sua solubilidade em água para valores menores do que $1 \mu \mathrm{g} \mathrm{L}^{-1}$ e o aumento do impedimento estérico nos seus sítios ativos resultam em uma diminuição da toxicidade aquática da substância, mas implicam na diminuição da sua biodegradabilidade. No entanto, é possível reduzir a toxicidade de uma substância sem concomitantemente aumentar sua persistência no ambiente, ou seja, sem diminuir sua biodegradabilidade. Por exemplo, a introdução de um grupo metil no 2-hidroxietilacrilato originando o 2-hidroxietilmetacrilato resulta em uma diminuição de toxicidade devido ao aumento do impedimento estérico, mas tem pouco efeito sobre sua biodegradabilidade..$^{31}$

A última etapa da cadeia de causalidade (etapa 3, Figura 2) diz respeito aos efeitos tóxicos provocados pelas substâncias químicas, seus metabólitos e produtos de conversão sobre os organismos aquáticos. Para isso, essas substâncias devem entrar em contato com um sítio alvo apropriado e reagir com ele em concentração e intervalo de tempo suficientes. O contato e a reação entre a substância química e o sítio alvo do organismo recebem o nome de exposição. Os organismos aquáticos podem ser expostos aos agentes químicos presentes na água, nos sedimentos e nos alimentos. Contaminantes solúveis em água são introduzidos nos organismos aquáticos por meio da superfície do corpo (exposição dérmica) e pelos tecidos respiratórios. Contaminantes presentes nos alimentos podem ser ingeridos (exposição oral) e absorvidos pelo trato gastrointestinal, enquanto que contaminantes adsorvidos em partículas e sedimentos podem penetrar no organismo por exposição dérmica ou respiratória, à medida que vão sendo dessorvidos para a água que está em contato com o organismo aquático. As rotas de exposição podem afetar a cinética de absorção, distribuição, biotransformação e excreção dos contaminantes e, dessa forma, podem influenciar sua toxicidade. ${ }^{14}$ Assim, a concentração ambiental de uma determinada substância não é necessariamente a concentração à qual os indivíduos de uma espécie estão expostos porque a dose biologicamente ativa de um contaminante diz respeito à quantidade deste contaminante que atinge as células, sítios e membranas onde ocorre a reação responsável pelos efeitos tóxicos do contaminante. ${ }^{18,32}$

Dentre os efeitos bioquímicos e fisiológicos provocados pelos agentes tóxicos podemos destacar: modificações na permeabilidade das membranas celulares; interferência na produção de ATP; inibição reversível ou irreversível de enzimas; distúrbios no metabolismo de lipídios, podendo resultar em alterações hepáticas; alterações nos sistemas enzimáticos microssomais, os quais são responsáveis pela biotransformação de xenobióticos; alteração na estrutura ou na atividade de enzimas que participam de processos reguladores, comprometendo a síntese e liberação de hormônios, bem como reduzindo a velocidade de crescimento dos organismos; distúrbios no metabolismo de carboidratos e distúrbios no processo respiratório pela inibição do transporte de elétrons e da fosforilação oxidativa. ${ }^{33}$

Contaminantes absorvidos podem ser retidos nos organismos e provocar efeitos deletérios quando níveis elevados são atingidos. Os processos de acumulação nos organismos envolvem a bioconcentração, a bioacumulção e a biomagnificação. A bioconcentração é o processo pelo qual uma substância química é absorvida do ambiente aquático pelo organismo por meio das superfícies respiratórias e dérmicas, ou seja, a exposição ao contaminante por meio da dieta alimentar não é incluída. A bioconcentração de um contaminante é a concentração retida no organismo resultante após os processos de assimilação e eliminação do mesmo. A eliminação do contaminante do organismo pode ocorrer por troca respiratória, excreção fecal, biotransformação metabólica do contaminante de origem e diluição resultante do crescimento. A diluição provocada pelo crescimento é considerada um processo de "pseudo-eliminação" desde que o contaminante não é realmente eliminado do organismo, mas tem sua concentração diminuída pelo aumento do volume dos tecidos nos quais ele se encontra. A bioacumulação é um termo mais abrangente que inclui todas as rotas de exposição ao contaminante, inclusive a dieta alimentar. $\mathrm{O}$ aumento da concentração de contaminantes nos tecidos à medida que se avança nos níveis tróficos, resultante principalmente da acumulação ocasionada pela dieta alimentar, recebe o nome de biomagnificação. ${ }^{34,35}$

Os efeitos deletérios provocados pela ação dos contaminantes nos organismos se propagam pelos demais componentes dos ecossistemas. Esses efeitos podem provocar modificações: nas características e dinâmica das populações (reprodução, migração, restabelecimento e mortalidade), na estrutura e função das comunidades (alteração na diversidade de espécies, modificações na relação predador-presa) e na função do ecossistema (alterações nos processos de respiração e fotossíntese e no fluxo de nutrientes). ${ }^{33}$

Devido à complexidade do ambiente aquático e ao grande número de processos aos quais está sujeito um contaminante neste ambiente, é difícil extrapolar para escala ambiental as informações provenientes dos testes de toxicidade realizados em laboratório. Além disso, devese considerar que, a princípio, devido às diversas condições abióticas e bióticas presentes nos ecossistemas aquáticos, não há nenhum 
organismo nem comunidade ecológica que possam ser usados para avaliar todos os efeitos possíveis sobre esses ecossistemas. Para que os efeitos em escala ambiental pudessem ser preditos a partir dos testes de toxicidade, as informações toxicológicas deveriam ser conectadas a modelos populacionais, o que é uma tarefa extremamente complicada que envolve uma série de restrições, principalmente de custo e tempo. Apesar disso, os testes de toxicidade realizados sob condições controladas e padronizadas vêm servindo como fonte de informações para avaliar os efeitos ecológicos de contaminantes tóxicos. ${ }^{2}$

\section{TESTES DE TOXICIDADE COM ORGANISMOS AQUÁTICOS}

A toxicidade é uma propriedade que reflete o potencial de uma substância em causar um efeito danoso a um organismo vivo. Ela depende da concentração e das propriedades da substância química à qual o organismo é exposto e também do tempo de exposição. ${ }^{14}$ Tradicionalmente, os testes de toxicidade aquática são utilizados para medir os efeitos tóxicos de substâncias particulares e de águas contaminadas. Os testes com substâncias específicas são realizados com o propósito de obter informações para registros químicos, enquanto que os testes com águas contaminadas são utilizados para verificar se há concordância dos valores obtidos com os padrões permitidos. Neste último caso, as águas podem ser coletadas em pontos de descarga de efluentes ou no próprio corpo d'água receptor. ${ }^{8}$ Dados de toxicidade são utilizados para comparar diferentes substâncias químicas, além de permitir comparar a sensibilidade de diferentes organismos aquáticos a uma mesma substância. ${ }^{14}$

É recomendável que o efeito tóxico de uma amostra seja avaliado para mais de uma espécie representativa da biota aquática, de preferência pertencentes a diferentes níveis tróficos da cadeia alimentar ${ }^{1,4,36}$ (Figura 4). Além de organismos pertencentes aos três níveis tróficos apresentados na Figura 4, testes de toxicidade com organismos decompositores, como rotíferos e bactérias, também podem ser utilizados. ${ }^{4} \mathrm{~A}$ utilização de uma bateria de testes com pelo menos quatro organismostestes de diferentes níveis de organização biológica pode ser apropriada para avaliar a ecotoxicidade de uma substância ou efluente. ${ }^{1,37}$ Isso é recomendado devido às diferenças de sensibilidade apresentadas por organismos de diferentes espécies frente às substâncias químicas. Além disso, não é possível extrapolar o efeito tóxico de uma substância sobre organismos de determinada espécie para organismos de outras espécies. ${ }^{36}$ Assim, sempre que possível, é recomendável avaliar o efeito de uma substância ou efluente para mais de uma espécie da biota aquática para que, por meio do resultado obtido com o organismo mais sensível,

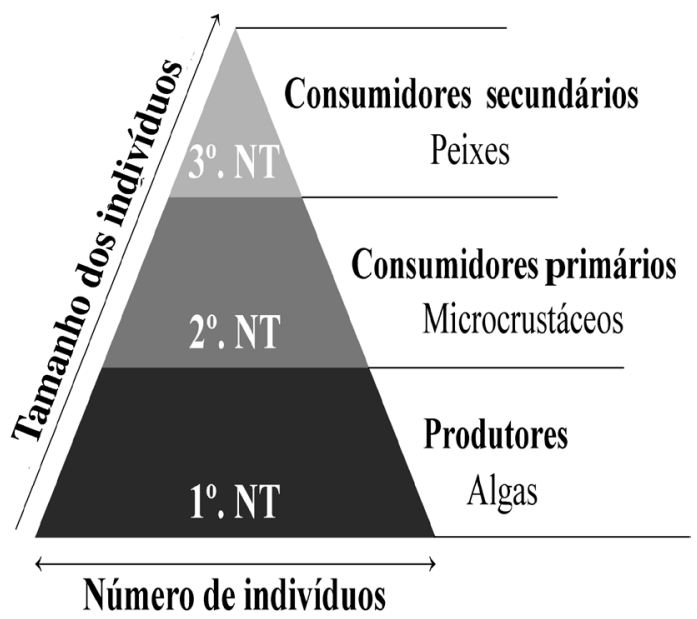

Figura 4. Um exemplo de cadeia alimentar do ecossistema aquático constituída por representantes de três níveis tróficos (NT) seja possível estimar com mais segurança o impacto do contaminante no corpo d'água receptor. ${ }^{4}$ Apesar disso, por razões práticas e econômicas, muitas vezes os testes de toxicidade são realizados com uma única espécie de organismo-teste. ${ }^{1}$

Em princípio, qualquer espécie aquática pode ser utilizada em testes de toxicidade. ${ }^{38}$ Entretanto, as espécies utilizadas nesses testes devem apresentar as seguintes características: ${ }^{5,14,39}$ seletividade constante e elevada aos contaminantes, elevadas disponibilidade e abundância, uniformidade e estabilidade genética nas populações, representatividade de seu nível trófico, significado ambiental em relação à área de estudo, ampla distribuição e importância comercial e, facilidade de cultivo e de adaptação às condições de laboratório. Além disso, devem ser utilizadas espécies cuja fisiologia, genética e comportamento sejam bem conhecidos, o que pode facilitar a interpretação dos resultados.

Um dos objetivos da ecotoxicologia é o desenvolvimento de protocolos de testes de toxicidade que permitam definir limiares de toxicidade permissíveis com níveis de incerteza aceitáveis e que sirvam de guia para as entidades reguladoras para a tomada de decisões. ${ }^{2}$ Diversos órgãos de proteção ambiental, como Environment Canada e Environmental Protection Agency dos Estados Unidos (U.S. EPA), e de padronização, como American Society for Testing and Materials (ASTM), Organisation for Economic Cooperation and Development (OECD), Association of Analytical Communities (AOAC) e International Organization for Standardization (ISO) têm se concentrado na elaboração e implementação de sistemas de diagnóstico, os quais constituem a base para a geração de estratégias que visam proteger os ecossistemas. ${ }^{2}$ A utilização de testes padronizados é vantajosa principalmente porque permite a seleção de um ou mais testes uniformes e úteis para uma variedade de laboratórios, facilita a comparação dos dados contribuindo para aumentar a utilização dos dados publicados e permite a reprodução dos testes. No Brasil, o órgão responsável pelo desenvolvimento de protocolos de testes de toxicidade é a Associação Brasileira de Normas Técnicas (ABNT). A Companhia de Tecnologia de Saneamento Ambiental do Estado de São Paulo (CETESB) também tem padronizado testes de toxicidade. Na Tabela 1 são apresentadas as principais normas brasileiras referentes a testes de toxicidade aquática para organismos pertencentes a diferentes grupos taxonômicos.

Os testes de toxicidade podem ser classificados em agudos e crônicos. Esses testes diferem na duração e nas respostas finais que são medidas. Os testes de toxicidade aguda são utilizados para medir os efeitos de agentes tóxicos sobre espécies aquáticas durante um curto período de tempo em relação ao período de vida do organismoteste. Eles têm como objetivo estimar a dose ou concentração de um agente tóxico que seria capaz de produzir uma resposta específica mensurável em um organismo-teste ou população, em um período de tempo relativamente curto, geralmente de 24 a 96 h. ${ }^{4}$ Os efeitos tóxicos medidos em testes de toxicidade aguda incluem qualquer resposta exibida por um organismo-teste ou população resultante de um estímulo químico. Normalmente, o efeito medido em estudos de toxicidade aguda com organismos aquáticos é a letalidade ou alguma outra manifestação do organismo que a antecede como, por exemplo, o estado de imobilidade. Os testes de toxicidade aguda permitem que valores de $\mathrm{CE}_{50}$ e $\mathrm{CL}_{50}$ (Tabela 2) sejam determinados por vários métodos estatísticos computacionais. Geralmente os valores de concentrações efetivas e letais são expressos em relação a 50\% dos organismos porque estas respostas são mais reprodutíveis, podem ser estimadas com maior grau de confiabilidade e são mais significativas para serem extrapoladas para uma população. No ambiente aquático, efeitos agudos provocados por agentes tóxicos nos organismos podem resultar de aplicações inadequadas de agrotóxicos, de acidentes ambientais e de situações em que efluentes industriais não tratados são lançados nos corpos d'água receptores. ${ }^{2,4,5,8,10,14,38}$ 
Tabela 1. Testes de toxidade padronizados pela ABNT e CETESB

\begin{tabular}{|c|c|c|c|}
\hline Organismo & Efeito & Espécie & Normas brasileiras \\
\hline Bactéria & Agudo & Vibrio fischeri & CETESB, L5.227 $7^{40}$ \\
\hline Bactéria & Agudo & Spirillum volutans & CETESB, L5.228 $8^{41}$ \\
\hline Alga & Crônico & $\begin{array}{c}\text { Chlorella vulgaris, Scenedesmus subspicatus, } \\
\text { Pseudokirchneriella subcapitata }\end{array}$ & CETESB, L5.020 $0^{42}$ e ABNT, NBR12648 43 \\
\hline Microcrustáceo & Agudo & Daphnia similis, Daphnia magna & CETESB, L5.018 $8^{44}$ e ABNT, NBR $12713^{45}$ \\
\hline Microcrustáceo & Agudo & Artemia salina & CETESB, L5.021 $1^{46}$ \\
\hline Microcrustáceo & Crônico & Ceriodaphnia dúbia, Ceriodaphnia silvestrii & CETESB, L5.022 $2^{47}$ e ABNT, NBR $13373^{48}$ \\
\hline Peixe & Agudo & Danio rerio, Pimephales promelas & CETESB, L5.019 ${ }^{49}$ e ABNT, NBR15088 50 \\
\hline
\end{tabular}

Testes de toxicidade crônica são realizados para medir os efeitos de substâncias químicas sobre espécies aquáticas por um período que pode abranger parte ou todo o ciclo de vida do organismo-teste. O fato de uma substância química não produzir efeitos tóxicos sobre organismos aquáticos em testes de toxidade aguda não indica que ela não seja tóxica para eles. Testes de toxicidade crônica permitem avaliar os possíveis efeitos tóxicos de substâncias químicas sob condições de exposições prolongadas a concentrações sub-letais, ou seja, concentrações que permitem a sobrevivência dos organismos, mas que afetam suas funções biológicas, tais como reprodução, desenvolvimento de ovos, crescimento e maturação, dentre outras. Os resultados obtidos em testes de toxicidade crônica são geralmente expressos como CENO ou CEO (Tabela 2), mas também podem ser expressos como $\mathrm{CE}_{50}$. $\mathrm{O}$ lançamento contínuo de efluentes aquosos

Tabela 2. Definição de alguns termos utilizados em testes de toxicidade

\begin{tabular}{|c|c|c|}
\hline Parâmetro & Definição & $\begin{array}{l}\text { Tempo de ex- } \\
\text { posição }\end{array}$ \\
\hline $\mathrm{DL}_{50}$ & $\begin{array}{l}\text { Dose Letal Média: dose de amostra } \\
\text { que causa mortalidade de } 50 \% \text { dos } \\
\text { organismos no tempo de exposição } \\
\text { e condições do teste. }\end{array}$ & 24 a 96 h \\
\hline $\mathrm{CL}_{50}$ & $\begin{array}{l}\text { Concentração Letal Média: concen- } \\
\text { tração de amostra que causa mor- } \\
\text { talidade de } 50 \% \text { dos organismos no } \\
\text { tempo de exposição e nas condições } \\
\text { do teste. }\end{array}$ & 24 a $96 \mathrm{~h}$ \\
\hline $\mathrm{CE}_{50}$ & $\begin{array}{l}\text { Concentração Efetiva Média: } \\
\text { concentração de amostra que causa } \\
\text { um efeito agudo (imobilidade, por } \\
\text { exemplo) a } 50 \% \text { dos organismos no } \\
\text { tempo de exposição e nas condições } \\
\text { do teste. }\end{array}$ & 24 ou $48 \mathrm{~h}$ \\
\hline CENO & $\begin{array}{l}\text { Concentração de Efeito não Ob- } \\
\text { servado: maior concentração de } \\
\text { agente tóxico que não causa efeito } \\
\text { deletério estatisticamente signifi- } \\
\text { cativo nos organismos no tempo de } \\
\text { exposição e nas condições do teste. }\end{array}$ & 7 dias \\
\hline $\mathrm{CEO}$ & $\begin{array}{l}\text { Concentração de Efeito Observado: } \\
\text { menor concentração de agente } \\
\text { tóxico que causa efeito deletério } \\
\text { estatisticamente significativo nos } \\
\text { organismos no tempo de exposição } \\
\text { e nas condições do teste. }\end{array}$ & 7 dias \\
\hline
\end{tabular}

tratados nos corpos d'águas pode provocar efeitos crônicos, uma vez que os organismos são expostos a certos contaminantes, mesmo em baixas concentrações, durante longos períodos de tempo. . $^{2,4,5,8,10,14,38}$

Os testes de toxicidade podem ainda ser classificados em estáticos, semi-estáticos e dinâmicos, de acordo com o método de adição das soluções-teste. ${ }^{5,15}$ Os ensaios estáticos são realizados sem renovação das soluções-testes e são recomendados para amostras que não causam depleção de oxigênio, que não são voláteis e que são estáveis em meio aquoso. ${ }^{5,50}$ Amostras com elevados valores de DBO e/ou DQO ou que contenham populações bacterianas em suas composições podem apresentar concentrações de oxigênio dissolvido menores do que as encontradas nas águas naturais o que pode provocar stress ou mortalidade dos organismos-teste, fazendo com que o resultado do teste de toxicidade seja superestimado. Por outro lado, substâncias tóxicas instáveis ou voláteis têm suas concentrações reduzidas ao longo do teste, contribuindo para que seu resultado seja subestimado. ${ }^{5,8}$ Nesses casos são recomendados os testes semi-estáticos, nos quais as soluções-testes são renovadas periodicamente. Nos testes semi-estáticos, o período de renovação das soluções-testes dependerá da espécie de organismo-teste. Para Danio rerio, por exemplo, recomenda-se que as soluções sejam renovadas a cada 24 h, enquanto que para Pimephales promelas o intervalo de tempo recomendado para a renovação das soluções é de $48 \mathrm{~h} .{ }^{50}$ Testes de toxicidade crônica de longa duração são geralmente realizados em modo dinâmico. ${ }^{15}$ Nos testes dinâmicos as soluções-testes são continuamente renovadas. ${ }^{8}$

Na Tabela 2 são definidos os parâmetros mais freqüentemente utilizados em testes de toxicidade. $\mathrm{A} \mathrm{DL}_{50}$ é um parâmetro normalizado pelo peso do organismo, ou seja, é expresso em mg de substância química por massa do organismo em kg. ${ }^{51} \mathrm{O}$ termo dose refere-se à quantidade de substância tóxica que entra no organismo e, portanto, pode ser inferior à dose à qual o organismo é exposto. ${ }^{5} \mathrm{DL}_{50}$ é um parâmetro bastante utilizado em farmacocinética e medicina. ${ }^{7}$ Os parâmetros $\mathrm{CL}_{50}, \mathrm{CE}_{50}, \mathrm{CENO}$ e $\mathrm{CEO}$, freqüentemente utilizados em ecotoxicologia aquática, são normalizados em função do ambiente em que os organismos são expostos. ${ }^{51}$ Por esse motivo, eles são expressos em termos da concentração ambiental da substância química, a qual é geralmente expressa em mg de substância por litro de solução preparada em água natural ou sintética apropriada (água de diluição). ${ }^{11}$ Os resultados dos testes de toxicidade para substâncias específicas são comumente expressos em $\mathrm{mg} \mathrm{L}^{-1}$, enquanto que para efluentes ou águas contaminadas os resultados são expressos em \%.

Os valores numéricos de toxicidade aguda e crônica, expressos como $\mathrm{CL}_{50}, \mathrm{CE}_{50}$, CENO e CEO, exprimem uma relação inversa à toxicidade, ou seja, menores valores numéricos indicam maiores toxicidades. ${ }^{4}$ Para facilitar a comparação e fazer com que esses parâmetros exprimam uma relação direta com a toxicidade, podem ser transformados em unidades tóxicas aguda (UT, ou crônica (UT c $_{\mathrm{a}}$ ) pelas seguintes Equações:4,52 
$\mathrm{UT}_{\mathrm{a}}=100 / \mathrm{CE}_{50}$ ou $\mathrm{UT}_{\mathrm{a}}=100 / \mathrm{CL}_{50}$

$\mathrm{UT}_{\mathrm{c}}=100 / \mathrm{CENO}$ ou $\mathrm{UT}_{\mathrm{c}}=100 / \mathrm{CEO}$

Dessa forma, quanto maior o valor numérico em unidade tóxica, maior será a toxicidade da amostra. Na Tabela 3 são apresentados valores de $\mathrm{CL}_{50}$ em \% e UT para Daphnia magna em diferentes efluentes industriais. ${ }^{52}$ Os resultados indicam a seguinte sequiência crescente de toxicidade: efluente $(3)<$ efluente $(4)<$ efluente $(5)=$ efluente (6) < efluente (2) < efluente $(1)<$ efluente (7).

Tabela 3. Toxicidades agudas de diferentes efluentes industriais para Daphnia magna após 48h. Adaptada da ref. 52

\begin{tabular}{lccc}
\hline Efluente & Origem do Efluente & $\mathrm{CL}_{50}(\%)$ & $\mathrm{CL}_{50}\left(\mathrm{UT}_{\mathrm{a}}\right)$ \\
\hline 1 & Hospital (1) & $0,4 \pm 0,2$ & 250,0 \\
2 & Hospital (2) & $33,2 \pm 6,6$ & 3,0 \\
3 & Fabricante de materiais & $70,8 \pm 15,2$ & 1,4 \\
& $\begin{array}{c}\text { para escritórios e escolas } \\
4\end{array}$ & Fabricante de peças para \\
& automóveis & $54,5 \pm 5,3$ & 1,8 \\
5 & Fabricante de produtos de & $51,0 \pm 11,4$ & 2,0 \\
6 & higiene & 2,0 \\
7 & Companhia farmacêutica & $49,1 \pm 10,3$ & 2,0 \\
\hline
\end{tabular}

A relação entre a concentração de uma substância química à qual é exposto um determinado organismo e o efeito nocivo que lhe é produzido, conhecida como relação dose-resposta, é um dos aspectos mais importantes da ecotoxicologia aquática. A relação dose-resposta constitui a base fundamental para a avaliação do risco gerado pelas substâncias químicas no meio ambiente porque permite quantificar a toxicidade aguda dessas substâncias. Em geral, as curvas que representam a relação dose-resposta apresentam comportamento não-retilíneo do tipo sigmóide, como ilustrado na Figura 5. ${ }^{9,51,53}$ Dois parâmetros importantes podem ser determinados a partir das curvas dose-resposta: a concentração ou dose, que resulta em $50 \%$ do efeito medido, ou seja, os valores de $\mathrm{CL}_{50}$ ou $\mathrm{CE}_{50}$ e, o coeficiente angular da porção linear da curva que passa pelo ponto correspondente à $\mathrm{CL}_{50}$ ou $\mathrm{CE}_{50}$. Os dois parâmetros são necessários para descrever precisamente a relação entre a concentração do agente químico e o efeito deletério provocado nos organismos-teste. Diferentes substâncias químicas podem apresentar diferentes valores de $\mathrm{CL}_{50}$ ou $\mathrm{CE}_{50}$, mas podem apresentar os mesmos valores de coeficientes angulares. Valores similares de coeficientes angulares podem indicar que os

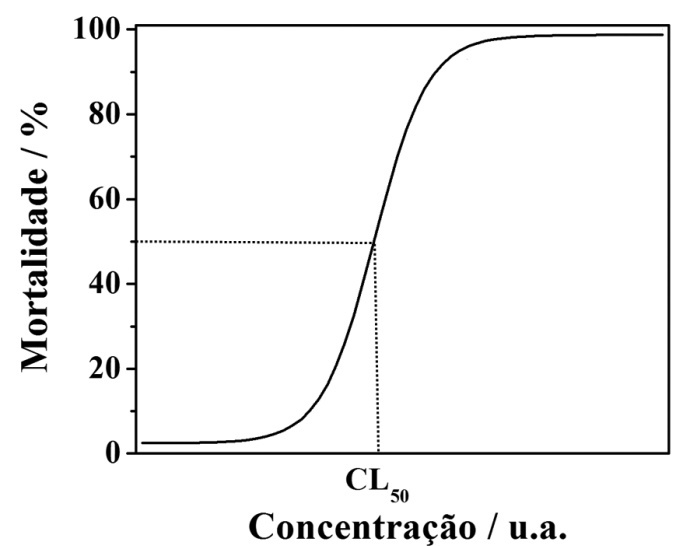

Figura 5. Representação de uma curva dose-resposta típica obtida em testes de toxicidade modos de ação das substâncias químicas analisadas são similares. Apesar de $\mathrm{CL}_{50}$ e $\mathrm{CE}_{50}$ serem comumente expressos em $\mathrm{mg} \mathrm{L}^{-1}$, a concentração molar fornece uma avaliação mais precisa, uma vez que a toxicidade de uma substância específica se relaciona ao número de moléculas dessa substância que interage com um sítio ativo. Outro problema refletido nos valores $\mathrm{CL}_{50}$ e $\mathrm{CE}_{50}$ é que expressam concentrações ambientais de substâncias tóxicas referentes a um determinado tempo de exposição, estabelecido para cada teste. Assim, uma substância que se move lentamente nos tecidos, por exemplo, pode apresentar uma toxicidade menor no período do teste, simplesmente pelo fato de sua concentração no tecido alvo não ter atingido níveis suficientes para provocar efeito tóxico durante o intervalo de tempo considerado. ${ }^{11,51}$

A estatística desempenha um papel importante no planejamento e execução dos testes de toxicidade e na análise e interpretação dos resultados obtidos nesses testes. Em geral, os métodos de análises dos resultados estão bem documentados, são aplicáveis à maioria dos dados obtidos nestes tipos de testes e podem ser manipulados por pessoas que não possuem conhecimentos de estatística. ${ }^{53}$

O método estatístico apropriado para analisar dados de toxicidade deve apresentar três características: ser razoavelmente preciso e acurado; ser programável, para que os cálculos possam ser realizados por um computador e, ser suficientemente robusto, o que significa que não deve falhar quando os dados forem atípicos. Quando um grande número de bioensaios é realizado, algumas anomalias podem ocorrer. O método estatístico escolhido deve ser capaz de estimar razoavelmente $\mathrm{CE}_{50}$ e $\mathrm{CL}_{50}$ a partir de tais dados anômalos. ${ }^{54}$

Dentre os métodos para determinar $\mathrm{CL}_{50}$ e $\mathrm{CE}_{50}$ encontram-se o método Probit, ${ }^{5,7}$ o método Logit ${ }^{5}$ e os métodos Spearman-Karber ${ }^{5}$ e trimmed Spearman-Karber. ${ }^{5,54}$ Os dois primeiros são métodos paramétricos que transformam os dados da curva dose-resposta em uma função matemática conhecida ou esperada antes dos valores de $\mathrm{CL}_{50}$ e $\mathrm{CE}_{50}$ serem estimados. Apresentam deficiências para contornar as anomalias apresentadas por alguns dados e não são válidos para curvas dose-resposta assimétricas. Os métodos Spearman-Karber e trimmed Spearman-Karber são métodos não paramétricos que não estão sujeitos a esses problemas, têm boas propriedades estatísticas, são fáceis de usar e recomendados para cálculos precisos de $\mathrm{CE}_{50} \mathrm{e}$ $\mathrm{CL}_{50}$ com intervalo de confiança de $95 \%$. Eles são válidos para curvas dose-resposta simétricas e assimétricas. A única limitação desses métodos em relação aos métodos paramétricos é que devem cobrir o intervalo de zero a $100 \%$ de mortalidade ou de efeito agudo. ${ }^{5,53,54}$

\section{Organismos utilizados em testes de toxicidade}

Algas

O uso de algas como indicador biológico é importante porque, como produtores primários, elas se situam na base da cadeia alimentar e qualquer alteração na dinâmica de suas comunidades pode afetar os níveis tróficos superiores do ecossistema. Dentre as vantagens em se utilizar algas em testes de toxicidade podemos destacar sua grande sensibilidade às alterações ocorridas no meio ambiente e o seu ciclo de vida relativamente curto, o que possibilita a observação de efeitos tóxicos em várias gerações. ${ }^{36}$

O efeito de inibição resultante sobre a população de algas, após um intervalo de tempo pré-estabelecido (geralmente 3 ou 4 dias), é determinado comparando-se o crescimento observado na presença de agente tóxico com o crescimento normal observado em um sistema livre de agente tóxico, o qual é chamado de controle. Nesses testes, a temperatura e a luminosidade devem ser rigorosamente controladas porque podem afetar significativamente o crescimento das algas. Para algas verdes de água doce, a temperatura recomendada é $24 \pm 2{ }^{\circ} \mathrm{C}$ e a intensidade de luz deve estar compreendida entre 80 e $120 \mu \mathrm{E} \mathrm{s}^{-1} \mathrm{~m}^{-2}$. 
Dependendo do número de concentrações de agente tóxico e do número de réplicas utilizadas nos testes de toxicidade com algas, $\mathrm{CE}_{50}, \mathrm{CENO}$ e CEO podem ser determinadas. ${ }^{23,55,56}$ Os resultados podem ainda ser comparados quanto à área sob a curva de crescimento obtida durante o período de 3 dias de teste, freqüentemente chamada de biomassa, ou pela velocidade de crescimento das algas. ${ }^{57}$

O crescimento algáceo pode ser determinado por contagem celular ao microscópio óptico ou com um contador eletrônico de partículas, pelo conteúdo de clorofila medido por espectrofotometria ou fluorimetria, ou pela turbidez medida em $750 \mathrm{~nm} \cdot{ }^{43}$ As algas verdes e unicelulares de água doce Chlorella vulgaris, Scenedesmus subspicatus e Selenastrum capricornutum (o gênero desta última foi formalmente modificado para Pseudokirchneriella subcapitata) são freqüentemente utilizadas em testes de toxicidade porque crescem rapidamente e suas culturas são facilmente preparadas em laboratório. ${ }^{23,43,57}$

Uma vez que a luz é um parâmetro imprescindível para o crescimento de algas, amostras que apresentam cor, como corantes e efluentes de indústrias têxteis, podem interferir nos testes de toxicidade com algas, levando a um resultado superestimado. Nesses casos, é difícil afirmar se o crescimento da população de algas foi realmente afetado pela interação da amostra com sítios alvos do organismo ou se simplesmente foi afetado porque parte da luz foi absorvida pela amostra. Além disso, como métodos ópticos como espectrofotometria e fluorimetria são sugeridos para determinar a concentração das algas, amostras com cor acentuada podem ser interferentes. ${ }^{36}$

\section{Crustáceos e peixes}

Crustáceos de água doce da ordem Cladocera e do gênero Daphnia, os quais são vulgarmente conhecidos como pulgas d'água, são bastante utilizados em testes de toxicidade porque são amplamente distribuídos nos corpos d'água doce, são importantes em muitas cadeias alimentares e são fonte significativa de alimento para peixes, possuem um ciclo de vida relativamente curto, são facilmente cultivados em laboratório, são sensíveis a vários contaminantes do ambiente aquático e porque, devido ao seu pequeno tamanho, necessitam de menores volumes de amostras-teste e água de diluição do que os testes realizados com algas e peixes. ${ }^{5,23,58}$ Além disso, a reprodução assexuada desses crustáceos por partenogênese garante a produção de organismos geneticamente idênticos permitindo, assim, a obtenção de organismos-teste com sensibilidade constante. ${ }^{59,60}$

Várias espécies de Daphnia são utilizadas em testes de toxicidade, mas, a mais utilizada é a Daphnia magna, para a qual existe um grande número de informação sobre as técnicas de cultivo, os requisitos de temperatura, luz e nutrientes e sobre sua resposta a muitas substâncias tóxicas. ${ }^{5,60}$ As espécies de Daphnia são basicamente diferenciadas pelo seu tamanho e essa característica tem influência sobre a toxicidade das substâncias. ${ }^{61}$ No Brasil, Daphnia similis vem sendo bastante utilizada em testes de toxicidade. ${ }^{60}$ Apesar de não ser uma espécie nativa, é facilmente cultivada em laboratório e atende os critérios estabelecidos pelos procedimentos padrões para a seleção de espécies alternativas. ${ }^{60,62}$

O crustáceo de água salgada Artemia salina também é uma espécie bastante utilizada em testes de toxicidade. ${ }^{63-65}$ A utilização dessa espécie é interessante porque seus ovos resistem à secagem e estocagem por longos períodos de tempo. Quando os ovos secos são colocados em água do mar e incubados a aproximadamente $23{ }^{\circ} \mathrm{C}$, eles eclodem dentro de 1 ou 2 dias e após isso os organismos já estão prontos para serem utilizados nos testes de ecotoxicidade. ${ }^{23}$ Os ovos de Artemia salina podem ser adquiridos em qualquer loja de artigos para aquários, uma vez que são utilizados como alimento para peixes. Nessas lojas também pode ser adquirido sal marinho para preparar água marinha artificial. O uso de Artemia salina é interessante quando se pretende avaliar a toxicidade de efluentes que apresentam alta sa- linidade e, portanto, alta condutividade, uma vez que esse parâmetro é um fator crítico para espécies de água doce.

O efeito tóxico freqüentemente avaliado em testes de toxicidade com microcrustáceos é a imobilidade porque, devido ao pequeno tamanho desses organismos, é difícil avaliar se estão mortos. ${ }^{23}$

Os principais representantes dos consumidores secundários nas cadeias alimentares são os peixes. ${ }^{4}$ Diversas espécies de peixes são utilizadas como bioindicadores. No Brasil a espécie mais utilizada é o Danio rerio, o qual é vulgarmente conhecido como peixe paulistinha ou peixe zebra. Pimephales promelas, o qual é popularmente conhecido como "Fathead minnow", também é utilizado em testes de toxicidade..$^{50} \mathrm{O}$ parâmetro avaliado nos testes de toxicidade aguda com peixes é a mortalidade e os testes de toxicidade crônica com esses organismos requerem longos períodos de tempo, uma vez que seu ciclo de vida e seu período reprodutivo são longos quando comparados aos de outras espécies. ${ }^{6}$

\section{Bactérias}

Embora tradicionalmente algas, crustáceos e peixes sejam usados para medidas de toxicidade aquática, esses testes requerem maiores tempo de exposição e volume de amostra do que testes de toxicidade que utilizam bactérias. Dentre esses, o teste que utiliza a bactéria marinha bioluminescente Vibrio fischeri e recebe o nome de Microtox é, sem dúvida, o mais utilizado. ${ }^{66-70}$ Nesse teste é medida a redução da luminescência emitida naturalmente pela bactéria quando ela é posta em contato com um agente tóxico, o qual inibe a atividade da enzima luciferase. O tempo de duração do teste varia entre 15 e $30 \mathrm{~min}$.

Microtox $^{\circledR}$ é um teste de toxicidade rápido, sensível, fácil de executar e de baixo custo que pode ser utilizado no controle da poluição das águas e efluentes industriais. Apesar dessas vantagens é um teste criticado por empregar uma bactéria marinha de pouco significado ecológico. ${ }^{6}$

\section{Efeitos aditivos, sinérgicos e antagônicos}

Em relação à toxicidade de misturas como, por exemplo, efluentes industriais, os efeitos resultantes das interações de seus constituintes podem ser classificados em: aditivos, sinérgicos e antagônicos. ${ }^{10,71,72}$ $\mathrm{O}$ efeito é aditivo quando a toxicidade da mistura é igual à soma das toxicidades individuais de seus componentes. ${ }^{71}$ Quando a toxicidade de uma mistura é maior que a soma das toxicidades dos seus constituintes há um efeito sinérgico e quando a toxicidade da mistura é menor que a soma das toxicidades de seus componentes, há um efeito antagônico. ${ }^{71}$ A ocorrência desses efeitos depende dos modos de interação entre os constituintes da mistura e o sítio alvo no organismo. Quatro tipos de interações são possíveis: ${ }^{10}$ os constituintes da mistura afetam a mesma função fisiológica; uma interação química entre os constituintes da mistura afeta a toxicidade de um dos químicos; a absorção, o metabolismo, a distribuição ou a excreção de um constituinte sofre alteração provocada pelos demais constituintes da mistura e, há uma competição entre os constituintes da mistura pelo mesmo tecido receptor. Na Tabela 4 são exemplificados os três tipos de interação. ${ }^{72}$

\section{Testes de toxicidade com sedimentos}

Testes de toxicidade aguda com sedimentos têm sido bastante utilizados em programas de avaliação e controle de sedimentos dragados para descarte em mares abertos ou águas continentais, de monitoramento de locais contaminados com descargas tóxicas e de triagem de áreas prioritárias. ${ }^{73}$ Esses testes são de baixo custo, relativamente simples e podem ser conduzidos com várias espécies. ${ }^{3}$

Diferentes bioensaios e organismos-teste têm sido empregados na 
Tabela 4. Toxicidades agudas de misturas binárias (intervalo de confiança de 95\%) determinadas por Microtox ${ }^{\circledR}$ após 15 min. Adaptada da ref. 72

\begin{tabular}{|c|c|c|c|c|}
\hline Misturas binárias & Efeito & $\mathrm{UT}_{\mathrm{a}}(\mathrm{A})$ & $\mathrm{UT}_{\mathrm{a}}(\mathrm{B})$ & $\mathrm{UT}_{\mathrm{a}}(\mathrm{A}+\mathrm{B})$ \\
\hline (A) $5 \mathrm{mg} \mathrm{L}^{-1}$ de $\mathrm{Zn}$ (II) & Aditivo & 3,09 & 2,73 & 6,23 \\
\hline (B) $90 \mathrm{mg} \mathrm{L}^{-1} \mathrm{de} \mathrm{Co}$ (II) & $\mathrm{UT}_{\mathrm{a}}(\mathrm{A}+\mathrm{B})=\mathrm{UT}_{\mathrm{a}}(\mathrm{A})+\mathrm{UT}_{\mathrm{a}}(\mathrm{B})$ & $(2,34-3,70)$ & $(2,39-3,14)$ & $(4,27-8,19)$ \\
\hline (A) $0,5 \mathrm{mg} \mathrm{L}^{-1} \mathrm{de} \mathrm{Cu}$ (II) & Sinérgico & 1,85 & 1,64 & 4,04 \\
\hline (B) $60 \mathrm{mg} \mathrm{L}^{-1}$ de $\mathrm{Cr}(\mathrm{VI})$ & $\mathrm{UT}_{\mathrm{a}}(\mathrm{A}+\mathrm{B})>\mathrm{UT}_{\mathrm{a}}(\mathrm{A})+\mathrm{UT}_{\mathrm{a}}(\mathrm{B})$ & $(1,78-1,91)$ & $(1,38-1,94)$ & $(3,72-4,36)$ \\
\hline (A) $4 \mathrm{mg} \mathrm{L}^{-1}$ de $\mathrm{Zn}$ (II) & Antagônico & 2,50 & 7,15 & 5,61 \\
\hline (B) $2 \mathrm{mg} \mathrm{L}^{-1} \mathrm{de} \mathrm{Cu}$ (II) & $\mathrm{UT}_{a}(\mathrm{~A}+\mathrm{B})<\mathrm{UT}_{a}(\mathrm{~A})+\mathrm{UT}_{a}(\mathrm{~B})$ & $(1,62-2,90)$ & $(6,61-7,32)$ & $(4,93-6,29)$ \\
\hline
\end{tabular}

avaliação da toxicidade de sedimentos. Entre os organismos-teste freqüentemente utilizados incluem-se microcrustáceos e macroinvertebrados bentônicos, os quais ocupam posições de consumidores nas cadeias alimentares da região pelágica (região que se estende desde a superfície até aproximadamente $200 \mathrm{~m}$ de profundidade) e bentônica (região situada próxima ao fundo oceânico e onde vivem organismos que rastejam, se prendem ou vivem enterrados na areia ou no lodo). Na região pelágica os microcrustáceos atuam como consumidores primários e secundários, enquanto que na região bentônica as larvas de insetos e também os microcrustáceos são importantes porque transformam os organismos vivos e a biomassa morta em alimento para outros consumidores. Devido às diferenças dos hábitos alimentares dos organismos das regiões pelágica e bentônica, é recomendado que a avaliação da toxicidade de sedimentos seja realizada com organismos de ambas as regiões. ${ }^{3}$

Os organismos bentônicos são os mais indicados para os testes de toxicidade com sedimentos porque vivem em contato direto com eles e com as águas intersticiais. Assim, alguns anfípodos, como Hyalella azteca, e larvas de insetos, como Chironomus xanthus, vêm sendo utilizados em vários estudos que envolvem a determinação da toxicidade de sedimentos. Apesar disso, são encontrados problemas em relação ao cultivo dessas espécies em laboratório e ao desenvolvimento de testes crônicos. Além disso, métodos padronizados com esses organismos ainda estão sendo desenvolvidos, o que faz com que o uso de testes padronizados com organismos não-bentônicos como, por exemplo, microcrustáceos do gênero Daphnia, seja preferido., ${ }^{3,74}$

Os testes com sedimento podem ser realizados com o sedimento total ou com a fração líquida dos mesmos (água intersticial ou solubilizado). Os testes com o sedimento total consistem na exposição de organismos a amostras de sedimento supostamente contaminadas com substâncias químicas. Ao final do período de exposição, variável de acordo com o teste utilizado, a resposta do organismo-teste é observada em relação a um determinado efeito adverso (mortalidade, crescimento, reprodução, citotoxicidade, alterações nas taxas de desenvolvimento ou respiração) e comparada estatisticamente com os resultados do controle e/ou sedimento de referência. ${ }^{73}$

Os testes com a fração líquida são realizados de acordo com os procedimentos descritos para amostras de água. Podem ser realizados com a água intersticial ou com o solubilizado. A água intersticial é formada pela interiorização da água durante o processo de sedimentação e a quantidade disponível da mesma depende diretamente da porosidade e indiretamente do tamanho e do grau de compactação das partículas. Existem diferentes métodos para extração da água intersticial como diálise, congelamento e centrifugação, sendo este último o mais utilizado. A solubilização é obtida por meio de lixiviação do sedimento com água destilada na proporção de uma parte de sedimento para quatro partes de água destilada. Após um período de agitação de 24 h, o sedimento é decantado e o líquido sobrenadante é retirado e submetido ao teste de toxicidade., ${ }^{3,5,73,74}$

Quando os testes são realizados com água intersticial assume-se que os contaminantes presentes nela e que causam toxicidade aos organismos-teste em laboratório são os mesmos que podem causar toxicidade nos sedimentos. Por outro lado, o solubilizado reflete di- retamente a interface sedimento/água uma vez que os contaminantes dos sedimentos não se restringem apenas aos organismos bentônicos, mas também podem afetar os organismos pelágicos por meio da ressuspensão dos sedimentos e liberação dos contaminantes neles adsorvidos. Assim, o solubilizado é a fase líquida que melhor representa esta última situação. Devido às diferenças apresentadas entre a água intersticial e o solubilizado, os resultados obtidos com testes de toxicidade em ambos os meios nem sempre são concordantes.

\section{Avaliação e identificação da toxicidade}

Amostras constituídas por substâncias de diferentes classes como, por exemplo, efluentes industriais podem apresentar componentes tóxicos e não tóxicos. Com o objetivo de isolar e identificar as substâncias tóxicas responsáveis pela toxicidade de efluentes, corpos d'água, águas intersticiais e sedimentos, métodos conhecidos como TIE (Toxicity Identification Evaluation) têm sido desenvolvidos como parte integrante dos protocolos de redução de toxicidade. Métodos TIE combinam a quantificação da toxicidade com a identificação e confirmação de uma ou mais substâncias e/ou classe de substâncias responsáveis pela toxicidade total de uma amostra. ${ }^{8,58,75}$

Métodos TIE compreendem três fases distintas. ${ }^{58,76} \mathrm{~A}$ fase I tem como objetivo caracterizar a natureza físico-química dos constituintes da amostra responsáveis pela sua toxicidade, por meio de manipulações ou tratamentos químicos e de testes de toxicidade aquática. Frações dessa amostra podem ser submetidas aos seguintes tratamentos físico-químicos: ajustes de $\mathrm{pH}$, o qual pode afetar a especiação de substâncias, como $\mathrm{S}^{2-}, \mathrm{CN}^{-}$e $\mathrm{NH}_{4}^{+}$; adição de agente quelante, o qual se complexa a íons metálicos, como $\mathrm{Cu}^{2+}, \mathrm{Cd}^{2+} \mathrm{e} \mathrm{Zn}^{2+}$; extração em fase sólida com coluna C18, a qual remove compostos orgânicos apolares, como pesticidas e COVs (Compostos Orgânicos Voláteis); adição de tiossulfato de sódio, o qual reduz espécies oxidantes, tais como $\mathrm{Cl}_{2}$ e $\mathrm{Cr}(\mathrm{VI})$; filtração, a qual remove partículas suspensas e substâncias cuja solubilidade é afetada pelo $\mathrm{pH}$ do meio; e outros. Testes de toxicidade aquática são realizados antes e após cada manipulação, o que permite avaliar a eficácia de cada tratamento e obter informação sobre a natureza das substâncias tóxicas. Após a fase I, fica claramente definida a classe ou classes de substâncias responsáveis pela toxicidade total da amostra. Na fase II, os estudos são conduzidos com o objetivo de identificar uma ou mais substâncias específicas responsáveis pela toxicidade da amostra. Assim, por exemplo, quando a classe de substâncias orgânicas é indicada na fase I como a principal responsável pela toxicidade de uma amostra, na fase II, essas substâncias serão isoladas e identificadas por técnicas analíticas específicas, como cromatografia líquida de alta eficiência, cromatografia gasosa, espectrometria de massas e outras técnicas. Na fase III, as substâncias tóxicas caracterizadas na fase I e identificadas na fase II são confirmadas por meio de testes químicos e toxicológicos adicionais.

A identificação de substâncias tóxicas é um passo fundamental para compreender as causas da toxicidade de amostras complexas, bem como para removê-las ou reduzir suas concentrações para níveis aceitáveis, principalmente quando se trata de efluentes industriais que serão lançados nos corpos d'água. 


\section{CONSIDERAÇÕES FINAIS}

Nesta revisão foram apresentados os principais processos físicos, químicos e biológicos nos quais um contaminante químico pode se envolver no ambiente aquático e que podem afetar a sua biodisponibilidade e toxicidade. Também foram discutidos os principais aspectos relacionados aos testes de toxicidade aguda e crônica, os parâmetros utilizados para expressar a toxicidade e os métodos estatísticos utilizados nos seus cálculos, as principais espécies utilizadas nos testes padronizados, o aditivismo, sinergismo e antagonismo das toxicidades dos contaminantes em misturas, os testes com sedimentos e os métodos TIE.

Os testes de toxicidade são importantes para avaliar o potencial de risco ambiental dos contaminantes, uma vez que somente as análises químicas não possibilitam esse tipo de avaliação. Além disso, análises de toxicidade já vêm sendo exigidas por leis ambientais no Brasil. No capítulo IV da Resolução ${ }^{\circ}$. 357 do Conselho Nacional do Meio Ambiente (CONAMA), referente às condições e padrões de lançamento de efluentes, é estabelecido nos $§ 1$ e 2 do artigo 34 que o efluente não deverá causar ou possuir potencial para causar efeitos tóxicos aos organismos aquáticos no corpo receptor e que os critérios de toxicidade devem se basear em resultados de ensaios ecotoxicológicos padronizados utilizando organismos aquáticos. Nesse contexto, essa revisão procurou esclarecer alguns aspectos relevantes sobre os testes de toxicidade, mostrando que apesar de ser difícil extrapolar para o ambiente as informações obtidas com esses testes, já que no ambiente aquático os contaminantes estão sujeitos a diversos processos bióticos e abióticos que não são reproduzidos no laboratório, eles são imprescindíveis para predizer possíveis efeitos tóxicos dos contaminantes no ambiente.

\section{AGRADECIMENTOS}

C. R. Costa agradece à FAPESP pelo financiamento de sua bolsa de doutorado.

\section{REFERÊNCIAS}

1. Ribo, J. M.; Environ. Toxicol. Water Qual. 1997, 12, 283.

2. Ronco, A.; Báez, M. C. D.; Granados, Y. P. Em Ensayos Toxicológicos y Métodos de Evaluación de Calidad de Aguas - Estandarización, Intercalibración, Resultados y Aplicaciones; Morales, G. C., ed.; Centro Internacional de Investigaciones para el Desarrollo: Ottawa, 2004, cap. 1.

3. Dornfeld, C. B.; Dissertação de Mestrado, Universidade de São Paulo, Brasil, 2002

4. Gherardi-Goldstein, E.; Bertoletti, E.; Zagatto, P. A.; Araújo, R. P. A.; Ramos, M. L. L. C.; Procedimentos para Utilização de Testes de Toxicidade no Controle de Efluentes Líquidos, Companhia de Tecnologia de Saneamento Ambiental (CETESB): São Paulo, 1990.

5. American Public Health Association, American Water Works Association, Water Environment Federation; Standard Methods for the Examination of Water and Wastewater, $20^{\text {th }}$ ed., American Public Health Association: Washington, 1998.

6. Harmel, V. C.; Dissertação de Mestrado, Universidade Regional de Blumenau, Brasil, 2004.

7. Zakrzewski, S. F.; Principles of Environmental Toxicology, American Chemical Society: Washington, 1994.

8. Kendall, R. J.; Anderson, T. A.; Baker, R. J.; Bens, C. M.; Carr, J. A.; Chiodo, L. A.; Cob III, G. P.; Dickerson, R. L.; Dixon, K. R.; Frame, L. T.; Hooper, M. J.; Martin, C. F.; McMurry, S. T.; Patino, R.; Smith, E. E.; Theodorakis, W. Em Casarett and Doull's Toxicology - The Basic Science of Poisons; Klaassen, C. D., ed.; $6^{\text {th }}$ ed., MacGraw-Hill: New York, 2001, cap. 29.
9. Hodgson, E. Em A Textbook of Modern Toxicology; Hodgson, E., ed.; $3^{\text {rd }}$ ed., John Wiley \& Sons: New Jersey, 2004, cap. 1.

10. James, R. C.; Roberts, S. M.; Williams, P. L. Em Principles of Toxicology: Environmental and Industrial Applications; Williams, P. L.; James, R. C.; Roberts, S. M., eds.; 2 ${ }^{\text {nd }}$ ed., John Wiley \& Sons: New York, 2000, cap. 1.

11. Yu, M.-H.; Environmental Toxicology: Biological and Health Effects of Pollutants, $2^{\text {nd }}$ ed., CRC Press: Boca Raton, 2005.

12. Stenersen, J.; Chemical Pesticides - Mode of Action and Toxicology, CRC Press: Boca Raton, 2004.

13. de Kruijf, H. A. M. Em Manual on Aquatic Ecotoxicology; de Kruijf, H. A. M.; de Zwart, D., eds.; Kluwer Academica Publishers: Dordrecht, 1988, cap. 4.

14. Rand, G. M.; Wells, P. G.; McCarty, L. S. Em Fundamentals of Aquatic Toxicology: Effects, Environmental Fate, and Risk Assessment; Rand, G. M., ed.; $2^{\text {nd }}$ ed., Taylor \& Francis: Washington, 1995, cap. 1.

15. Adams, W. J.; Rowland, C. D. Em Handbook of Ecotoxicology; Hoffman, D. J.; Rattner B. A.; Burton Jr., G. A.; Cairns Jr., J., eds.; $2^{\text {nd }}$ ed., Lewis Publishers: Boca Raton, 2003, cap. 2.

16. Slooff, W. Em ref. 13, cap. 17.

17. Ravera, O.; Ann. Chim. (Rome, Italy) 2004, 94, 495.

18. Holt, M. S.; Food Chem. Toxicol. 2000, 38, S21.

19. Shea, D. Em ref. 9, cap. 27

20. Leblanc, G. A. Em ref. 9, cap. 26.

21. Meent, D.-v. Em ref. 13, cap. 9.

22. Lyman, W. J. Em ref. 14, cap. 15.

23. Shaw, I. C.; Chadwick, J.; Principles of Environmental Toxicology, Taylor \& Francis: Philadelphia, 1998.

24. Alberici, R. M.; Tese de Doutorado, Universidade de Campinas, Brasil, 1996.

25 Baird, C.; Química Ambiental, tradução: Recio, M. A. L.; Carrera, L. C. M.; 2a ed., Bookman: Porto Alegre, 2002.

26. Bruggeman, W. A. Em ref. 13, cap. 9.

27. Bartels, P.; Tümpling Jr., W. V.; Sci. Total Environ. 2007, 374, 143.

28. Little, E. E.; Calffe, R. D.; Theodorakos, P.; Brown, Z. A.; Johnson, C. A.; Environ. Sci. Pollut. Res. 2007, 14, 333

29. Corami, F.; Capodaglio, G.; Turetta, C.; Bragadin, M.; Calace, N.; Petrônio, B. M.; Ann. Chim. (Rome, Italy) 2007, 97, 25.

30. Lamelas, C.; Slaveykova, V. I.; Environ. Sci. Technol. 2007, 41, 4172.

31. Boethling, R. S.; Sommer, E.; DiFiore, D.; Chem. Rev. 2007, 107, 2207.

32. Hermens, J. L. M.; Heringa, M. B.; Laak, T. L.; J. Toxicol. Environ. Health, Part A 2007, 70, 727.

33. Connell, D. W.; Miller, G. J.; Chemistry and Ecotoxicology of Pollution, John Wiley \& Sons: New York, 1984.

34. Arnot, J. A.; Gobas, F. A. P. C.; Environ. Rev. 2006, 14, 257.

35. Spacie, A.; McCarty, L. S.; Rand, G. M. Em ref. 14, cap. 16.

36. Reginatto, V.; Tese de Doutorado, Universidade de Campinas, Brasil, 1998.

37. Castillo, G. C.; Vila, I. C.; Neild, E.; Environ. Toxicol. 2000, 15, 370.

38. van Leeuwen, C. J. Em ref. 13, 1988, cap. 18.

39. Ronco, A.; Báez, M. C. D.; Granados, Y. P. Em ref. 2, cap. 3.

40. Companhia de Tecnologia de Saneamento Ambiental (CETESB); Norma técnica L5.227, Teste de toxicidade com a bactéria luminescente Vibrio fischeri: método de ensaio, São Paulo, 2003.

41. Companhia de Tecnologia de Saneamento Ambiental (CETESB); Norma técnica L5.228, Teste de toxicidade aguda utilizando Spirillum volutans: método de ensaio, São Paulo, 1988.

42. Companhia de Tecnologia de Saneamento Ambiental (CETESB); Norma técnica L5.020, Água - teste de toxicidade com Chlorella vulgaris: método de ensaio, São Paulo, 1991.

43. Associação Brasileira de Normas Técnicas (ABNT); Norma Técnica NBR12648, Ecotoxicologia aquática - Toxicidade crônica - Método de 
ensaio com algas (Chlorophyceae), 2 ${ }^{\text {a }}$. ed., Rio de Janeiro, 2005.

44. Companhia de Tecnologia de Saneamento Ambiental (CETESB); Norma técnica L5.018, Água - teste de toxicidade aguda com Daphnia similis Claus, (Cladocera, Crustacea): método de ensaio, São Paulo, 1994.

45. Associação Brasileira de Normas Técnicas (ABNT); Norma Técnica NBR12713, Ecotoxicologia aquática - Toxicidade aguda - Método de ensaio com Daphnia spp (Crustacea, Cladocera), Rio de Janeiro, 2004.

46. Companhia de Tecnologia de Saneamento Ambiental (CETESB); Norma técnica L5.021, Água do mar - teste de toxicidade aguda com Artemia: método de ensaio, São Paulo, 1991.

47. Companhia de Tecnologia de Saneamento Ambiental (CETESB); Norma técnica L5.022, Água - avaliação de toxicidade crônica, utilizando Ceriodaphnia dubia Richard, 1894 (Cladocera, crustacea): método de ensaio, São Paulo, 1994

48. Associação Brasileira de Normas Técnicas (ABNT); Norma Técnica NBR13373, Ecotoxicologia aquática - Toxicidade crônica - Método de ensaio com Ceriodaphnia spp (Crustacea, Cladocera), $2^{\text {a }}$. ed., Rio de Janeiro, 2005.

49. Companhia de Tecnologia de Saneamento Ambiental (CETESB); Norma técnica L5.019, Água - teste de toxicidade aguda em peixes; método de ensaio, São Paulo, 1990.

50. Associação Brasileira de Normas Técnicas (ABNT); Norma Técnica NBR15088, Ecotoxicologia aquática - Toxicidade aguda - Método de ensaio com peixes, $2^{\mathrm{a}}$. ed., Rio de Janeiro, 2004.

51. Leblanc, G. A. Em ref. 9, cap. 11.

52. Villegas-Navarro, A.; Santiago, M. R.; Pérez, F. R.; Rodríguez, R.; Environ. Int. 1997, 23, 535.

53. Báez, M. C. D.; Rossini, G. D. B.; Granados, Y. P. Em ref. 2, cap. 5.

54. Hamilton, M. A.; Russo, R. C., Thurston, R.V.; Environ. Sci. Technol. 1977, 11, 714

55. Granados, Y. P.; Ronco, A.; Báez, M. C. D. Em ref. 2, cap. 4.5.

56. Lewis, M. A. Em ref. 14, cap. 4.
57. Cleuvers, M.; Weyers, A.; Water Res. 2003, 37, 2718.

58. Cooney, J. D. Em ref. 14, cap. 2.

59. Tatarazako, N.; Oda, S.; Watanabe, H.; Morita, M.; Igushi, T.; Chemosphere 2003, 53, 827.

60. Buratini, S. V.; Bertoletti, E.; Zagatto, P. A.; Bull. Environ. Contam. Toxicol. 2004, 73, 878.

61. Vesela, S.; Vijverberg, J.; Aquat. Ecol. 2007, 41, 67.

62. Beatrici, A. C.; Trabalho de Conclusão de Curso, Universidade Federal do Rio Grande do Sul, Brasil, 2001.

63. Mathews, R. S.; Free Radical Biol. Med. 1995, 18, 919.

64. Nguyen, H.; Ogwuru, N.; Duong Q.; Eng, G.; Appl. Organomet. Chem. 2000, 14, 349.

65. Nunes, B. S.; Carvalho, F. D.; Guilhermino, L. M.; Stappen, G. V.; Environ. Pollut. 2006, 144, 453.

66. Zwart, D. D.; Slooff, W.; Aquat. Toxicol. 1983, 4, 129.

67. Coleman, R. N.; Qureshi, A. A.; Bull. Environ. Contam. Toxicol. 1985 , 35, 443.

68. Boluda, R.; Quintanilla, J. F.; Bonilla, J. A.; Sáez, E.; Gamón, M.; Chemosphere 2002, 46, 355.

69. Parvez, S.; Venkataraman, C.; Mukherji, S.; Environ. Int. 2006, 32, 265.

70. Wadhia, K.; Thompson, K. C.; Trends Anal. Chem. 2007, 26, 300.

71. Panouillères, M.; Boillot, C.; Perrodin, Y.; Ecotoxicology 2007, 16, 327.

72. Ince, N. H.; Dirilgen, N.; Apikyan, L. G.; Tezcanli, G.; Üstün, B.; Arch. Environ. Contam. Toxicol. 1999, 36, 365.

73. Abessa, D. M. S.; Sousa, E. C. P. M.; Tommasi, L. R.; Revista de Geologia 2006, 19, 253.

74. Ingersoll, C. G. Em ref. 14, cap. 8.

75. Filho, R. W; de Araújo, J. C.; Vieira, E. M.; Quim. Nova 2006, 29, 817.

76. http://www.environmental-expert.com/articles/article1210/article1210. htm, acessada em Setembro 2007. 